\title{
A method for modifying MMA mix with rubber fines used in asphalt concrete mix plants
}

\author{
Karolina Bednarczyk ${ }^{1}$, Paweł Rajczyk ${ }^{2}$
}

\begin{abstract}
:
One way of improving the production process for asphalt concrete pavements is their modification with plasticizers or additives. The current tendency, when searching for innovative methods to increase the quality of manufactured asphalt concrete mixtures, is their modification with rubber dust, which is one way of improving the hardness characteristics of asphalt concrete pavements while, at the same time, minimizing environmental hazards through efficient material usage. The use of rubber from used car tires in the production of asphalt concrete mixtures proves to be an effective method for their management.
\end{abstract}

\section{KEYWORDS:}

asphalt mix; modification; rubber dust; MMA; production technology

\section{Introduction}

The introduction of modifying additives and plasticizing admixtures in the general modernization of production, consisting of complex processes is referred to as the technology of road materials. Specialist groups of road engineers deal with the knowledge of the theoretical foundations aimed at obtaining new material composites. The main focus is on the relationship between the physical or mechanical properties of the finished composite materials and their structure. The structure of road materials includes an assessment of the type and form of bonds between atoms, electrons and ions and the way they are arranged. Thermodynamics plays a significant role in the analysis of technological processes, especially in the case of the absorption and the release of heat or energy transfer. One way of increasing the quality of asphalt concrete is modifying it with the addition of dust or rubber granules obtained from car tires in terms of technological analysis of MMA manufacturing and corporate processes.

\section{Types of asphalt concrete}

Asphalt concrete is a compacted asphalt-mineral mix, which consists of two different components: a mineral mix and an asphalt binder [1-4]. Due to the structure, the following types of mixtures are understood: concrete, macadam and intermediate, the structures of which are shown in Figure 1.

Concrete type (MMA) is characterized by an even graded graining (MM) according to a harmonious graining curve made of aggregates of various grain sizes. The mixture after compaction should contain a minimum amount of voids, which are filled with an appropriate

${ }^{1}$ Czestochowa University of Technology, Faculty of Civil Engineering, ul. Akademicka 3, 42-218 Częstochowa, e-mail: karolina.bednarczyk.97@wp.pl

2 Czestochowa University of Technology, Faculty of Civil Engineering, ul. Akademicka 3, 42-218 Częstochowa, e-mail: rajczyk.pawel@wip.pcz.pl, orcid id: 0000-0001-5363-7337 
amount of binder, after compaction the MMA obtains the required strength and roughness. This type includes asphalt concrete, mastic asphalt, and sand asphalt.

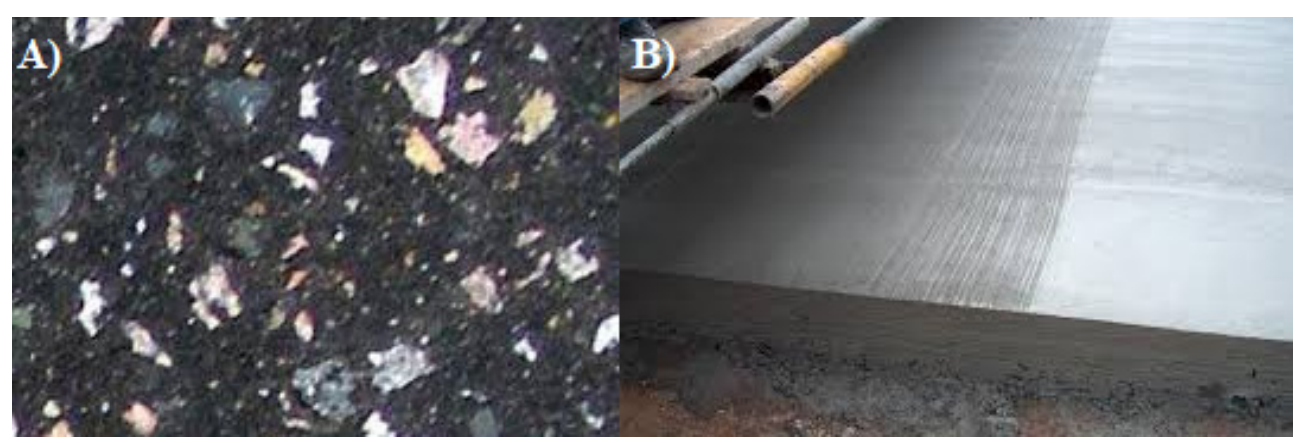

Fig. 1. Structure of road pavements: a) macadam pavement, b) concrete pavement [5]

The macadam type (MMA) consists of single fraction aggregate varnished with asphalt or sprinkled with asphalt in situ directly on the road which is built in layers with gradually decreasing grain size of subsequent fractions during compaction. Mixtures of this type due to the so-called free space $(20 \%)$ is called an open-structure mixture.

The intermediate MMA type is characterized by the fact that this type has a particle size distribution curve where no intermediate fractions are present.

In the description of the literature [6] it is stated that rubber granulate can be incorporated into asphalt mixtures by a dry process or wet process. The dry method consists of adding rubber granules to the mineral mix, which replaces the mineral aggregate fractions. The dry method adds rubber that has a grain size of $0 \div 2 \mathrm{~mm}$, in the amount of $2 \div 3 \%$, where a mixture with rubber dust inclusions is obtained. The addition of rubber reduces the stiffness of the mixture, which increases its resistance to cracking. The wet method consists of modifying the asphalt binder with rubber dust added in the amount of $15 \%$ to the asphalt mass. Asphalt is mixed with rubber in a special installation at a temperature of $190 \div 230^{\circ} \mathrm{C}$ for at least 45 minutes. During the thermal treatment process, the asphalt reacts with the rubber, which swells and softens. After mixing the rubber with the asphalt, the rubber-asphalt binder should be stored at high temperature for at least 2 hours. Properties of asphalt mixtures modified with rubber dust are characterized by increased resistance to rutting at low temperatures of the abrasive layer and reduced noise exposure. The significance of this modification is particularly important in terms of the properties of the asphalt binder itself. Apart from its advantages, asphalt also has disadvantages, one of which is the high dependence of its hardness on temperature. In Poland, temperatures can drop to $-30^{\circ} \mathrm{C}$, while in summer the air temperature in June can be as high as $+35^{\circ} \mathrm{C}$, the pavement temperature can be as high as $+60^{\circ} \mathrm{C}$. The temperature deviation interval is $90^{\circ} \mathrm{C}$. Surfaces made of hard asphalts do not rut in summer but crack in winter, while surfaces made of soft asphalts do not crack in winter, but deform in summer. Therefore, one of the solutions to this problem is the modification of asphalts with rubber dust. Rubber-asphalt binders and mineral-rubber asphalt mixtures can be used in the construction of road surfaces for waterproofing bridges and bicycle paths. The properties and suitability of ground rubber for asphalt modification depend on many factors, including the type of rubber, grinding method, and size and shape of ground particles. The crushed rubber granules can be divided into the following types: rubber dust $<0.2 \mathrm{~mm}$, rubber fines $0.2 \div 1.0 \mathrm{~mm}$, granules $1 \div 10 \mathrm{~mm}$, grit $>10 \mathrm{~mm}$, rubber shreds up to $40 \mathrm{~mm}$.

Fine particles in the form of rubber dust occur using the cryogenic method, while the rest of the group uses mechanical methods. For the production of rubber-asphalt binder, dust or rubber fines with a grain size up to $1 \mathrm{~mm}$ are used. 


\section{Modifying MMA mixes with rubber dust}

In order to increase the durability of the pavement for road safety and increase the pro-ecological characteristics by reducing traffic noise, modifiers in the form of rubber dust obtained from the processing of car tires are used. This method of managing used car tires is the most effective for the pro-ecological economy. For example, for asphalt modification, approximately 1,200 passenger car tires are used for every $1 \mathrm{~km}$ of road lane with a $5 \mathrm{~cm}$ thick abrasive layer. It should be noted that this is the most economical way of recycling used rubber materials. In addition, the modified asphalt mass with rubber dust reduces the braking distance by $20 \%$, an important parameter of road safety. One of the methods of improving pavement characteristics is the modification of their composition by adding dust to the asphalt in the so-called hot MMA modification process or by adding dust to the mineral-asphalt mixture of dust or rubber granules in the so-called cold modification technique (dry process). The modification process is slow. At a temperature of about $100^{\circ} \mathrm{C}$, the mixing time is about 1 hour. Rubber powder mixed with asphalt stored at $200^{\circ} \mathrm{C}$ for 20 minutes doubles its volume [7]. The rubber particles become softer and more elastic. Depending on the method of production Figures 2 and 3 , the binders can be produced as stored or non-stored $[8,9]$, asphalt-rubber binder can be stored without changing its properties for a period of 2 weeks.

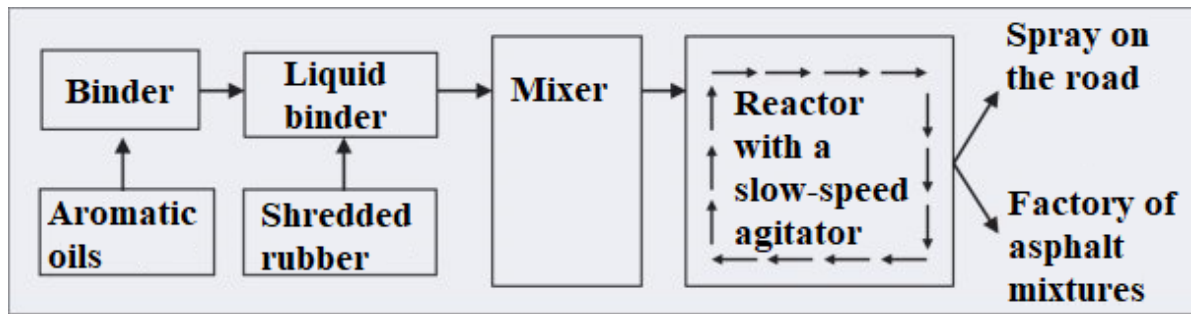

Fig. 2. Production of non-stored asphalt-rubber binder [10]

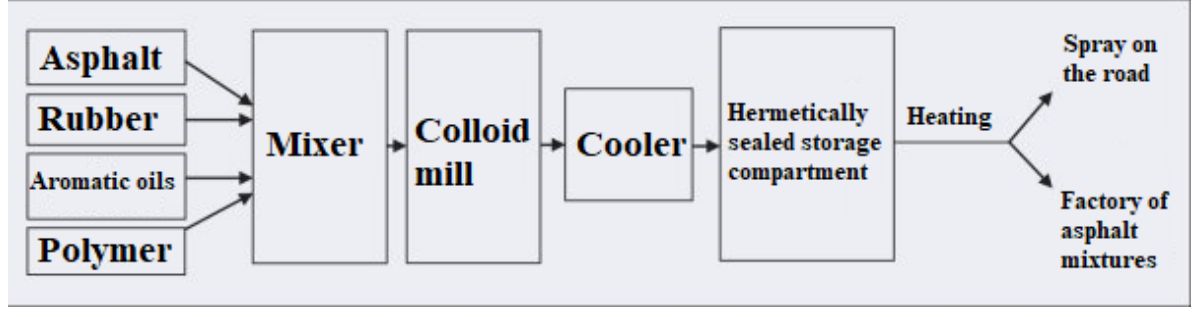

Fig. 3. Production of stored rubber-asphalt binder [10]

Rubber-asphalt binders are characterized by an improvement in technical properties compared to typical asphalts used in road construction:

- increases to the temperature of resistance to permanent deformation,

- reduces temperature sensitivity,

- are characterized by an increase in viscosity.

- have extended temperature range of visco-elasticity,

- improved low temperature properties,

- reduced susceptibility to aging.

Temperature sensitivity is a measure of the thermal stability of the binder. It is advantageous when the binder shows small changes in hardness as a function of temperature change, the measure of this value is the penetration index, which for the rubber-asphalt binder is over +1 (standard requirements from $0 \div+2$ ), the viscosity of the asphalt-rubber binder increases at a pavement temperatures of $60 \div 80^{\circ} \mathrm{C}$ which increases resistance to rutting. In the case of using asphalt-rubber binder in precision tools at low temperatures, the tests showed lower 
hardening than unmodified asphalt and higher ductility. Breaking point of rubber-asphalt binder acc. Fraassa is $70 \%$ higher in relation to the breaking point of non-modifiable asphalt. The addition of asphalt rubber delays aging by the presence of oxidation inhibitors in the rubber. The use of asphalt binder modified with asphalt in the production of asphalt mixtures is characterized by many advantages of pavements made with their participation, including: improving anti-skid properties, increasing the resistance of the layer to aging, increasing durability, improving resistance to rutting, increasing fatigue life, reducing noise exposure and vibrations during operation and reduction of operating costs. Road surfaces with rubber-asphalt binder are characterized by increased durability, which reduces operating costs $[11,12]$.

\section{Analysis of the test factors for the modified binder of rubber dust}

Cracks in MMA are most often formed in the plane of connection of the binder with the aggregate. It was assumed that one of the features positively influencing the properties (MMA) is the adhesion of the binder to the aggregate surface. The tests were based on the experiments described in $[13,14]$ of the tests of breaking the MMA particles produced on granite aggregates with an area of $10 \mathrm{~cm}^{2}$ bonded with a binder with different contents of rubber granules for road asphalts of the 35/50,50/70, 70/100 type. Figure 4 presents the results of tests for asphalts most often used in production plants (MMA) 50/70.

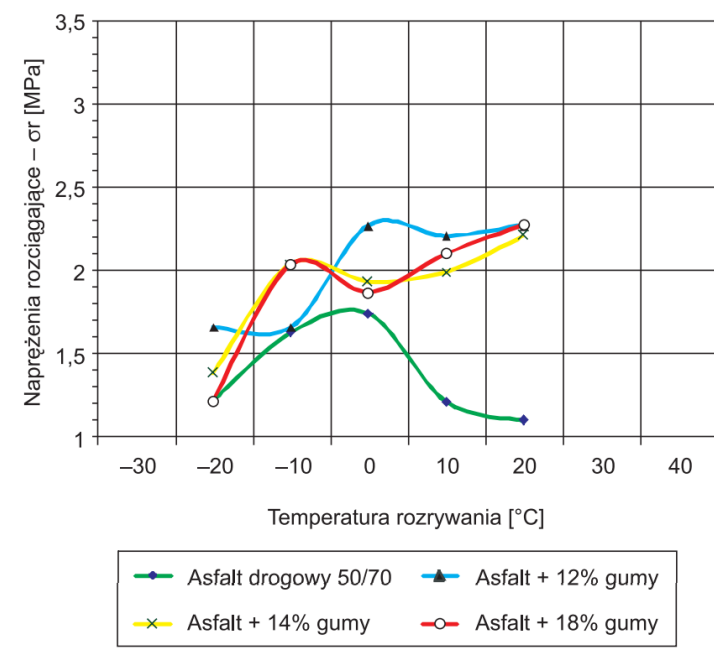

Fig. 4. The results of the tensile strength tests of MMA samples with asphalt binder 50/70 modified with rubber dust [14]

The test results presented in Figure 4 show the increased tensile strength for samples with a modified asphalt binder with a rubber additive in the temperature range from $-30^{\circ} \mathrm{C}$ to $+20^{\circ} \mathrm{C}$. Characteristically, significant strength is obtained at temperatures of $0^{\circ} \mathrm{C}$ and above than at temperatures lower than $<0^{\circ} \mathrm{C}$ as compared to unmodified rubberized asphalt. Based on the pilot study, it was found that rubber-modified asphalt binders have higher adhesion to the aggregates of the mixtures compared to unmodified asphalt. This phenomenon is exacerbated by the addition of $2 \div 4 \%$ to the asphalt agent in the form of a modified biofuel.

\section{Conclusions}

Rubber-asphalt binders and mineral-rubber-asphalt mixtures are characterized by an increased durability period. Such mixtures can be used for the construction of road surfaces of various traffic categories for water protection of bridges. Pavements built with rubber-asphalt 
binders are characterized by reduced susceptibility to reflection and low-temperature cracking, the possibility of reducing the thickness of the road surface, and improving the resistance to surface damage. Surfaces constructed of such a mixture, improves driving comfort and traffic safety, increases the roughness coefficient for the wheel of the vehicle, and reduces noise emissions.

The aforementioned operational benefits due to the management of rubber waste and the expensive possibility of using pavement recycling, reduces the energy consumption of production processes, thus reducing $\mathrm{CO}_{2}$ emissions.

The economic calculation shows the advisability of using asphalt modifiers and asphalt mixtures with an additive in the form of crushed rubber from used tires, which can be a fullyfledged and cheaper replacement for other polymers used in asphalt modification.

For the production of rubber-asphalt binders, in practice, 50/70 and 70/100 starting asphalts are used, to which an addition in the form of rubber fines in the amount of $15 \div 20 \%(\mathrm{~m} / \mathrm{m})$ and plasticizers in the amount of $2 \%(\mathrm{~m} / \mathrm{m})$ are used. The conducted laboratory tests showed an increased adhesion of the binder to aggregates in (MMA) compared to unmodified asphalt.

\section{References}

[1] Telegina M., Kirillova D., Lazarev Y., Petrov V., Temperature condition of asphalt concrete during road usage, Lecture Notes in Civil Engineering 2020, 70, 177-189.

[2] Piłat P., Radziszewski P., Nawierzchnie asfaltowe, Wydawnictwo Komunikacji i Łączności, 2005.

[3] Głowacka A., Porowatość nawierzchni - zaleta czy wada? Drogownictwo nr 3, 2002.

[4] Rajczyk M., Rajczyk P., Rajczyk J., Test of asphalt working from a mill from the frez from the exploded asphaltobetone layers of road surfaces, Key Engineering Materials, 828 KEM, 2020, 158-162.

[5] Kukiełka J., Nawierzchnie asfaltowe dróg samorządowych, Politechnika Lubelska, Lublin 2013.

[6] Makovetskaya-Abramova O., Iwanow A., Lazarev Y., Szachowa M., Rozov A., Economic assessment of construction of the roadside service facilities, E3S Web of Conferences, nr 157, 2020.

[7] Horodecka R., Kalabińska M., Piłat J., Radziszewski P., Sybilski D., Wykorzystanie zużytych opon samochodowych w budownictwie drogowym. IBDiM, zeszyt 54, Warszawa 2002.

[8] Kurakina E., Evtiukov S., Impact of static and dynamic loads of vehicles on pavement, E3S Web of Conferences, nr 164, 2020

[9] Caltrans, Asphalt rubber usage guide, Materials Engineering and Testing Services, 2006.

[10] http://www.inzynierbudownictwa.pl/technika,materialy_i_technologie,artykul,zastosowane_lepiszczy_gumowo asfaltowych_do_nawierzchni_drogowych,6408.

[11] Bashkarev A.Y., Kudravtseva N.N., Rajczyk J., Correlation between asphalt concrete strength, amount of bitumen and asphalt mix batching modes, Procedia Engineering 2015, 117(1), 66-72.

[12] Bashkarev A.Y., Bespalova N.N., Rajczyk J., Influence of hot asphalt concrete preparation technology on its strength, Applied Mechanics and Materials 2014, 1197-1201.

[13] Sybilski D., Zastosowanie odpadów gumowych w budownictwie drogowym, Przegląd Budowlany 2009, 5, 37-44.

[14] Koba H., Szydło A., Wpływ asfaltów modyfikowanych gumą na przyczepność skał, Drogownictwo 2010, 6 , 198-201.

\section{Metoda modyfikowania mieszanki MMA miałem gumowym stosowana w wytwórniach mieszanek asfaltobetonowych}

\section{STRESZCZENIE:}

Jednym z kierunków doskonalenia technologii produkcji nawierzchni asfaltobetonowych jest ich modyfikacja plastyfikatorami lub dodatkami. Aktualne tendencje w zakresie innowacyjnych poszukiwań sposobów zwiększania jakości produkowanych mieszanek asfaltobetonowych jest ich modyfikacja pyłem gumowym który jest jednym z kierunków poprawy cech twardości nawierzchni asfaltobetonowych i jednocześnie kierunkiem utylizacji materiału, dla minimalizacji zagrożeń ekologicznych. Wykorzystywanie gumy ze zużytych opon samochodowych w technologii wytwarzania mieszanek asfaltobetonowych wykazuje efektywny sposób ich zagospodarowania.

SŁOWA KLUCZOWE:

mieszanka asfaltowa; modyfikacja; pył gumowy; MMA; technologia produkcji 